\title{
PENDAMPINGAN TERHADAP IBU-IBU DAN REMAJA PUTERI PADA PELATIHAN PEMBUATAN HANTARAN PENGANTIN DI PKBM 01 KEMAYORAN JAKARTA PUSAT
}

\author{
Karnadi \\ Jurusan PLS, Fakultas Ilmu Pendidikan, Universitas Negeri Jakarta
}

\begin{abstract}
ABSTRAK
Rendahnya penguasaan keterampilan hidup pada ibu-ibu dan remaja putri menyebabkan status sosial ekonomi mereka cukup memprihatinkan. Demikian pula para ibu dan remaja putri di PKBM 01 Kemayoran Jakarta Pusat, Diantara para Ibu, ada yang berpenghasilan tapi rendah, ada pula yang tidak berpenghasilan atau hanya mengandalkan penghasilan dari suami mereka

Kondisi keprihatinan sosial ekonomi ini menuntut berbagai upaya yang harus dicari solusinya.Pengabdian pada masyarakat ini bersifat pendampingan. Pendampingan ialah proses saling hubungan dalam bentuk ikatan pertemanan antara pendamping instruktur (subjek 1) dengan komunitas ibu-ibu dan remaja putri (subjek 2) melalui dialog-kritis, pelatihan-pelatihan dan pendidikan berkelanjutan dalam rangka menggali dan pengelolaan sumber daya guna memecahkan persoalan kehidupan sosial ekonomi subyek yang didampingi. Program pendampingan mengenai keterampilan hantaran pengantin merupakan suatu program yang menekankan kepada kecakapan hidup warga belajar agar dapat meningkatkan penghasilan.

Metodelogi pengabdian pada masyarakat ini dilakukan dengan pemberian teori dan praktek langsung Hasil pendampingan menunjukan bahwa berbagai pengetahuan, sikap dan keterampilan peserta dalam membuat hantaran pengantin berbeda antara sebelum pelatihan dan setelah pelatihan.Hal ini dibuktikan dengan hasil pre tes dan hasil pos tes.Hal ini berarti adanya manfaat dari pelatihan keterampilan hantaran pengantin ini.Pelatihan ini mampu menjadikan peserta berwawasan dan trampil mempraktekan pembuatan hantaran pengantin.Adapun sebelum pelatihan, peserta tidak memiliki wawasan bahwa kain itu dapat dilipat dan dibuat menjadi benda-benda yang lebih menarik apabila dibuat dalam bentuk dan lipatan sedemikian rupa. Setelah pelatihan, mereka mampu menunjukan bahwa hasil pelatihan yakni keterampilan mereka dalam membuat hantaran pengantin itu dapat membuka peluang usaha bagi mereka, mampu menjadikan mereka percaya diri dan secara bertahap dapat menambah penghasilan pada mereka.
\end{abstract}

Kata Kunci :Keterampilan, ibu, remaja, peluang usaha

\section{PENDAHULUAN}

Rendahnya sosial ekonomi masyarakat Indonesia memerlukan berbagai upaya serius dan intensif, yang memungkinkan masyarakat menjadi lebih aktif dan penuh inisiatif. Pemberdayaan masyarakat merupakan upaya untuk memandirikan masyarakat, melalui perwujudan potensi kemampuan yang mereka miliki.

Pengembangan potensi masyarakat dapat diwujudkan melalui kegiatan pendidikan yang berbasis kemasyarakatan, demi pengembangan potensi mereka, demi terpenuhinya kebutuhan mereka dan pemecahan permasalahan sosial ekonomi mereka. Pelaksanaan pendidikan luar sekolah ditujukan untuk memberikan pelayanan pendidikan kepada masyarakat yang tidak terlayani pada jalur pendidikan sekolah.

Salah satu kegiatan pendidikan luar sekolah untuk peningkatan kehidupan sosial ekonomi mereka adalah pelatihan keterampilan hidup atau life skill. Life skill atau kecakapan hidup adalah kemampuan yag mencakup penguasaan pengetahuan, keterampilan dan sikap yang saling berinteraksi sebagai unsur penting untuk hidup lebih mandiri. Secara umum tujuan pendidikan dengan orientasi life skill yang diselenggarakan melalui jalur pendidikan luar sekolah (PLS) adalah untuk meningkatkan pengetahuan, keterampilan dan sikap warga belajar dibidang tertentu sesuai dengan bakat dan minatnya sehingga mereka memiliki bekal kemampuan untuk bekerja atau berwirausaha yang dapat mendatangkan 
penghasilan yang layak guna memenuhi kebutuhan hidupnya.

Pelatihan keterampilan dapat memberikan pengetahuan untuk peningkatan kehidupan yang lebih berkualitas pada pesertanya.

Salah satu pelatihan keterampilan itu adalah pelatihan pembuatan hantaran pengantin.

Salah satu bentuk keterampilan hidup (life skills) adalah hantaran pengantin.Hantaran pengantin merupakan salah satu jenis keterampilan yang memanfaatkan kain-kain perca yang tidak terpakai lagi yang dibentuk sedemikian rupa sehingga menjadi kemasan hantaran pengantin, keterampilan ini tidak menggunakan banyak modal atau uang.

Pusat kegiatan belajar masyarakat (PKBM) merupakan satuan program pendidikan luar sekolah yang dioperasionalkan secara komperehensif, fleksibel dan terbuka bagi seluruh kelompok usia. Umberto Sihombing menjelaskan bahwa program kegiatan di PKBM menyiapkan warga belajarnya menuju kemapanan secara ekonomi atau self sufficient economy."Artinya tidak boleh menciptakan kegiatan hanya sekedar menghabiskan biaya, namun tidak dapat mengganti atau melipatkan gandakan biaya yang dikeluarkan tersebut, kegiatan harus diarahkan pada hal-hal yang bersifat produktif.Dana yang sangat kecil dapat memantapkan kehidupan seseorang apabila digunakan untuk mendukung kegiatan belajar yang mengarah pada mata pencaharian yang laku dijual.

Salah satu PKBM yang mengadakan kegiatan keterampilan adalah PKBM 01 Kemayoran Jakarta Pusat. PKBM ini memberikan macam-macam keterampilan yang kemudian dapat menjadikan warga belajarnya produktif.Salah satu kegiatan keterampilan di PKBM 01 Kemayoran ini adalah program keterampilan hantaran pengantin. Jumlah warga belajar program keterampilan jenis hantaran pengantin di PKBM 01 Kemayoran ini berjumlah 20 orang yang terdiri dari 15 orang Ibu-Ibu rumah tangga dan 5 orang remaja putri.

Masalahnya adalah pelatihan pembuatan hantaran pengantin ini seringkali mengalami kesulitan untuk dilaksanakan, karena masyarakat umumnya tidak menyadari pentingnya pelatihan pembuatan hantaran pengantin sebagai media pemecahan kesulitan sosial ekonomi mereka. Diantara mereka ada yang berpenghasilan tapi rendah, ada pula yang tidak berpenghasilan atau hanya mengandalkan penghasilan dari suami mereka.Kondisi keprihatinan sosial ekonomi ini menuntut berbagai upaya yang harus dicari solusinya. Pendampingan ialah proses saling hubungan dalam bentuk ikatan pertemanan antara pendamping instruktur (subjek 1) dengan komunitas ibu-ibu dan remaja putri (subjek 2) melalui dialog-kritis, pelatihanpelatihan dan pendidikan berkelanjutan dalam rangka menggali dan pengelolaan sumber daya guna memecahkan persoalan kehidupan sosial ekonomi subyek yang didampingi. Program pendampingan melalui pelatihan keterampilan hantaran pengantin ini berada pada jalur pendidikan luar sekolah. Program pendampngan mengenai keterampilan hantaran pengantin merupakan suatu program yang menekankan kepada kecakapan hidup warga belajar agar dapat meningkatkan penghasilan.

Melihat kenyataan di lapangan, baik itu pada masalah yang nampak maupun pada potensi-potensi yang dapat dimanfaatkan, dalam rangka peningkatan pendapatan ibu-ibu dan remaja putri, maka diperlukan adanya upaya pemecahan masalah dengan strategi penyelenggaraan pendampingan melalu pelatihan keterampilan hantaran pengantin. Kegiatan ini diharapkan dapat difasilitasi oleh Lembaga Pengabdian Pada Masyarakat Universitas Negeri Jakarta sebagai penyandang dana.

\section{RUMUSAN MASALAH}

Rumusan masalah pada pengabdian ini adalah "Apakah pendampingan melalui pelatihan pembuatan hantaran pengantin itu dapat menciptakan keterampilan hidup ibu-ibu dan remaja puteri di RW 01 Kemayoran ?

Secara rinci rumusan masalah di atas, diuraikan dalam bentuk pertanyaan-pertanyaan sebagai berikut:

1. Bagaimanakah Perencanaan Pelatihan pembuatan hantaran pengantin pada ibuibu dan remaja puteri di RW 01 Kemayoran?

2. Bagaimana Pelaksanaan Pelatihan pembuatan hantaran pengantin pada ibuibu dan remaja puteri di RW 01 Kemayoran? 
3. Apakah Pelatihan pembuatan hantaran pengantin dapat meningkatkan kemampuan keterampilan hidup pada ibu-ibu dan remaja puteri di RW 01 Kemayoran?

\section{LANDASAN TEORI}

\section{Pendidikan Luar Sekolah dan Pendampingan}

Pendidikan pada hakikatnya

merupakan suatu usaha sadar yang dilakukan untuk mengembangkan kepribadian dan kemampuan manusia di dalam maupun diluar sekolah. Dalam UU Sisdiknas tahun 2003 istilah pendidikan formal, nonformal dan informal dipergunakan kembali. Dijelaskan bahwa pendidikan nonformal adalah jalur pendidikan diluar pendidikan formal yang dapat dilaksanakan secara terstruktur dan berjenjang. Adapun pendidikan informal adalah jalur pendidikan keluarga dan lingkungan.Pemberdayaan masyarakat merupakan salah satu bentuk kegiatan Pendidikan Luar Sekolah adalah

Pendampingan berasal dari kata "damping" yang berarti sejajar (tidak ada kata atasan atau bawahan). Pendamping adalah perorangan atau lembaga yang melakukan pendampingan, dimana antara kedua belah pihak (pendamping dan yang didampingi) terjadi kesetaraan, kemiteraan, kerjasama dan kebersamaan tampa ada batas golongan (kelas atau status sosial) yang tajam.

Subejo dan Supriyanto (2004) menyebutkan bahwapemberdayaan masyarakat adalah upaya yang disengaja untuk memfasilitasi masyarakat lokal dalam merencanakan, memutuskan dan mengelola sumberdaya lokal yang dimiliki melalui collective action dan networking sehingga pada akhirnya mereka memiliki kemampuan dan kemandirian secara ekonomi, ekologi, dan sosial".Pemberdayaan masyarakat diantaranya dilaksanakan melalui program pendidikan kecakapan hidup.

\section{Kecakapan hidup}

Kecakapan hidup menurut WHO (1987) adalah "berbagai kemampuan untuk dapat beradaptasi dan berperilaku positif, yang memungkinkan seseorang mampu menghadapi berbagai tantangan dalam hidupnya seharihari. Kecakapan hidup ini menurut Brolling
(BPPLS:2008) dapat dikelompokan menjadi tiga bagian, yaitu : (1) Kecakapan hidup sehari-hari atau daily living skill (2) Kecakapan bidang pribadi dan sosial atau personal and sosial skill), (3) Kecakapan hidup bekerja atau Occupational Skill.

Sasaran life skill adalah mereka yang tidak berpendidikan, terutama anak-anak yang putus sekolah, serta remaja, pemuda, dan orang dewasa yang tidak memiliki keterampilan sama sekali.

\section{METODOLOGI, HASIL DAN PEMBAHASAN}

Metodelogi pengabdian pada
masyarakat ini dilakukan dengan
pendampingan melalui pemberian teori dan
praktek.Hasil pendampingan menunjukan
bahwa pengetahuan, sikap dan keterampilan
yang ditampilkan peserta pada saat pos test,
berbeda dengan hasil pre-test.

Alat untuk mengukur tingkat keberhasilan kegiatan ini adalah dengan membandingkan kegiatan sebelum dan sesudah penyampaian materi pelatihan pembuatan hantaran pengantin.

Pada pre-tes peserta ditanya secara lisan, dan diminta mempraktekan bagaimana membuat hantaran pengantin.Pada pre-tes peserta menjawab yang memper- lihatkan kurangnya pengetahuan dan keterampilan mereka.Mereka menyebutkan belum pernah membuat hantaran pengantin.Tidak pernah terpikir caranya membuat hantaran pengantin itu.

Pada pos-tes, peserta pelatihan umumnya menjawab dengan benar dan lengkap tentang pelaksanaan pembuatan hantaran pengantin.Para peserta juga cukup trampil memprak -tekan pembuatan hantaran pengantin itu. Peserta memperlihatkan skill mereka dalam memanfaatkan kain menjadi bentuk menyerupai binatang, dengan melipat dan mengkreasikannya sedemikian rupa sehingga tampak lucu dan bernilai seni. Hal ini sangat menarik dan menjadikan mereka memiliki skill yang dapat menjadi peluang usaha untuk bertambahnya pendapatan mereka. 


\section{PEMBAHASAN}

Setelah melakukan pelatihan pembuatan hantaran pengantin dari kain, para ibu dan remaja putri di PKBM 01 Kemayoran di Jakarta Pusat menjadi sadar tentang pentingnya skill didalam hidup mereka.Pelatihan ini telah turut mendukung pemerintah untuk memberdayakan masyarakat. Pelatihan itu jua telah berguna untuk membangun kemandirian peserta. Hal ini sesuai dengan upaya pemerintah untuk membangun kemandirian masyarakat.

Para peserta merespon dan berpartisipasi aktif dan meminta instruktur untuk memonitornya. Peserta pelatihan memiliki ketrampilan, pengetahuan dan sikap mental percaya diri untuk merintis usaha melalui pelatihan hantaran tersebut.

Pertimbangan pelatihan dilakukan di PKBM 01 Kemayoran ini karena banyak salon yang memungkinkan lebih tepat untuk menjual jasa pembuatan hantaran pengantin.Pelatihan di PKBM 01 Kemayoran di Jakarta Pusat ini, turut mendukung suksesnya pembinaandan pendampingan masyarakat.

Usaha membuat hantaran pengantin dari kain ini dapat dilakukan dengan modal usaha kecil. Usaha ini dapat dilakukan oleh anggota satu keluarga dan warga sekitarnya. Dengan demikian usaha ini menyediakan lapangan kerja baru. Pada pelatihan ini juga dikenalkan berbagai alat-alat dan bahan serta contoh pembuatan hantaran pengantin yang akan dilakukan. Kepada peserta pelatihan, juga ditanamkan jiwa kewirausahaan, seperti tumbuhnya rasa percaya diri, berani mengambil resiko dalam mengembangkan pembuatan hantaran pengantin, sikap kepemimpinan, seperti mau menerima saran dari pihak lain, sikap inovatif pada berbagai proses pembuatan hantaran pengantin.

Peserta pelatihan juga dibimbing untuk memiliki sejumlah keterampilan dan keahlian dibidang pembuatan hantaran pengantin seperti, teknik pemilihan bentuk yang akan dibuat apakah menyerupai binatang atau menyerupai bunga dan lain-lain. Sikap mental maupun kerja keras dalam membuat hantaran pengantin yang sabar, tekun dan cermat yang terjadi pada peserta pelatihan sebagaimana diuraikan di atas pada hakekatnya menjadi nilai utama yang diharapkan tumbuh pada diri peserta pelatihan.
Melalui pelatihan ini, diharapkan peserta pelatihan dapat meningkat skillnya sebagai upaya untuk merintis usaha dan meningkatkan oendapatan mereka.Pelatihan ini diharapkan dapat meningkatkan kemampuan peserta dan sekaligus secara bertahap peserta memiliki taraf kehidupan yang meningkat, khususnya secara sosial ekonomi.

\section{KESIMPULAN DAN SARAN}

Kesimpulan hasil pendampingan yaitu bahwa hasil pelatihan ketrampilan melakukan praktek pembuatan hantaran pengantin ini benar-benar mampu memberikan wawasan pengetahuan,sikap yang efektif dan keterampilan yang optimal.

\section{DAFTAR PUSTAKA}

[1] Dirjen PLSP. (2004). Menuju masyarakat yang cerdas, teampil, dan mandiri. Jakarta : Direktorat pendidikan Masyarakat. Depdiknas.

[2] Edi Suharto, Membangun masyarakat, memberdayakan rakyat: kajian strategis pembangunan kesejahteraan sosial dan pekerjaan sosial, Refika Aditama. Bandung. 2005

[3] Harry Hikmat. Strategi pemberdayaan masyarakat.Humaniora Utama Press.Bandung. 2006.

[4] http :/www. Delivery.org.(pember-dayaan masyarakat dalam praktek)

[5] Margono, S. (2000). Memantapkan posisi dan meningkatkan peran penyuluhan pembangunan dalam pembangunan. Dalam Proseding Seminar IPB Bogor: Pemberdayaan Sumber Daya Manusia Menuju Terwujudnya Masyarakat Madani. Pustaka Wira Usaha Muda.

[6] Miles, M. B. A. Michael Huberman. (1992). Analisa Data Kualitatif, Buku Tentang Metode-metode Baru, Jakarta : PenerbitUniversitas Indonesia UI Press.

[7] Moleong, Lexy J (1996). Metodologi Penelitian Kualitatif. Bandung : Remaja Rosdakarya.

[8] PemProv DKI Dikmenti sub Dinas PLS (2005) "Pedoman penyeleng- garaan PKBM di Provinsi DKI Jakarta. Jakarta. 
[9] Umberto Sihombing. (1999). "Pendidikan luar sekolah Kini dan masa depan". Jakarta.

[10] .................................(2000). Pendidikan Luar Sekolah. Manajemen Strategi. Konsep, Kiat, dan Pelaksana. Jakarta

[11] Ditjen PLS. (2003). "Standar Minimal Manajemen PKBM berbasis Masyarakat” Bandung. BPKB Jayagiri.

[12] Sajogyo, Bunga Rampai Perekonomian Desa, Yayasan Obor Indonesia, 1982.
[13] Sumaryo.1991. Implementasi Participatory Rural Appraisal (PRA) dalam Pemberdayaan Masyarakat. Disampaikan dalam Pelatihan Pengorgani- sasian Masyarakat dalam rangka Peningkatan Mutu Pengabdian pada Masyarakat, di IAIN Raden Intan Bandar Lampung, 26 November 2005.

[14] .....................(1996). Berbuat bersama, berperan setara. Konsorsium Pengembangan Dataran Tinggi Nusa Tenggara. Jakarta. 